\title{
FEATURES OF SOCIAL AND ECONOMIC DEVELOPMENT OF THE SOUTHERN UKRAINE IN THE FIRST HALF XIX OF CENTURY IN THE CONTEXT OF M.E. SLABCHENKO'S RESEARCHES
}

\section{Natalya Dianova}

DSc (History), Professor

Odessa I. I. Mechnikov National University

2, Dvoryanska Str., Odessa, 65082, Ukraine

dzess2009@rambler.ru

In the submitted scientific article the attempt of a research of features of social and economic development of the Southern Ukraine of the prereform period in the context of M. Slabchenko's researches is made. Sources of foreign colonization in the south and assessment of this process in M. Slabchenko's works are considered. The researcher considered policy of the government on in

volvement of foreign immigrants wrong and economically unreasonable.

It is shown that the basis and fast development of the cities was characteristic of social and economic development of the Southern Ukraine. On the basis of the processed sources $M$. Slabchenko claimed that process of the urbanization on lands of the South was carried out quickly enough. It is confirmed by statistical data of 1851.

Considering formation of urban population of $M$. Slabchenko a priority part assigned to merchants which have changed a petty-bourgeois image of the cities to bourgeois. In the context of the studied subject scientific interest submit the published and archival documents which give the chance to consider some aspects of the presented subject.

Mikhail Eliseevich's concept about a crucial role of the trade capital in development of society and the Black Sea ports in economic history of Ukraine is analyzed.

Key words: social and economic development, $M$. Slabchenko, southern Ukraine, cities, trade, merchants.

наталія діанова

Доктор історичний наук, професор Одеський національний університет імені I. I. Мечникова Вум. Дворянська, 2, Одеса, 65082, Україна dzess2009@rambler.ru

\section{ОСОБАИВОСТІ СОЦІААЬНО-ЕКОНОМІЧНОГО РОЗВИТКУ ПІВДЕННОЇ УКРАЇНИ В ПЕРШІЙ ПОАОВИНІ ХІХ СТ. В КОНТЕКСТІ ДОСАІДЖЕНЬ М. С. СААБЧЕНКА}

У поданій науковій розвідиі здійснено спробу дослідження особливостей соиіально-економічного розвитку Південної України дореформеного періоду через призму досліджень м. Слабченка. Розглянуто витоки іноземної колонізаиї на Півдні та оиінку иього проиесу в праиях М. Слабченка. Дослідни вважав урядову політику по залученню іноземних переселениів невірною й економічно необтрунтованою.

Показано, шо вагомою ознакою соиіально-економічного піднесення Південної Украӥни стало заснування та швидкий розвиток міст. На основі 
опрацьованих джерел М. Слабченко доводив, ио проиес урбанізаиії на землях Півдня здійснювався досить стрікко. Це знайшло своє підтвердження в статистичних даних 1851 p.

Розглядаючи формування міського населення М. Слабченко дотримувався тези про провідну роль купеитва, яке змінило мішанський вигляд міст на буржуазний. У контексті досліджуваної проблематики науковий інтерес становлять опубліковані та архівні документи, які дають можливість розглянути деякі аспекти поданої для розгляду теми.

Проаналізовано кониепиію Михайла Єлисейовича про вирішальну роль торгового капіталу в розвитку суспільства та причорноморсъких портів у економічній історії Украӥни.

ключові слова: соиіально-економічний розвиток, М. Слабченко, Південна Україна, міста, торгівля, купеитво.

Соціально-економічна історія України залишається однією 3 важливих проблем, які розробляються сучасною історичною наукою. Значна частина досліджень 3 даної проблематики носить регіональний характер. Одним із важливих регіонів, який мав свої особливості соціально-економічного розвитку, що сприяло стрімкому піднесенню упродовж XIX ст., був південь України. Урахування реального історичного досвіду дає можливість поглибити розуміння процесів, які відбуваються на сучасному етапі.

Проблема соціально-економічного розвитку України першої половини XIX ст., у тому числі й Південної, знайшиа своє відображення в історичній мітературі. Серед істориків, чиї праці безпосередньо стосувалися зазначеної теми, варто відзначити М. Слабченка [15] та О. Оглобліна [6]. Зокрема, Михайло Єлисейович Слабченко одним із перших у першій чверті XX ст. зробив спробу систематизувати i проаналізувати значну кількість джерел та досліджень з економічносоціальної історії України XIX ст., що знайшло узагальнення в монографії "Матеріали до економічно-соціальної історії України ХІХ ст.",

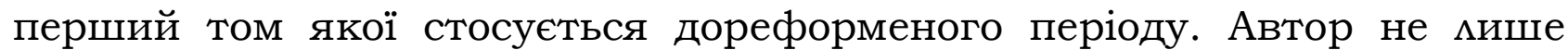
проаналізував розвиток української економіки в зазначений період, але й розглянув важелі впливу на неї з боку російського уряду. Помітне місце в його дослідженні посідає теза про економічне піднесення Півдня за рахунок причорноморських портів, які відігравали провідну роль у соціально-економічному розвитку України. У сучасній історіографії з'явилися праці, які стосуються внеску М. Слабченка в соціальноекономічну історію України. Серед них вагоме місце посідають дослідження Б. Винара, С. Водотики, Т. Гончарука, В. Заруби, А. Санцевича та ін.

Мета поданої публікації полягає у висвітленні особливостей соціально-економічного розвитку Південної України через призму дослідження даної проблеми М. Слабченком.

Михайло Єлисейович дотримувався думки, що на середину XIX ст. відбувся розподіл економічних інтересів між Західною та Східною Європою як промисловим та сільськогосподарським регіонами. У цих умовах значно зросло значення хлібної торгів $і$, а разом із нею $i$ 
чорноморських портів. Він був переконаним, що українське господарство було об’єднаним і тяжіло до причорноморських портів, через які відбувався зв'язок із європейським ринком, що зумовило його прагнення найбільш повно дослідити соціально-економічний розвиток Південної України на тмі загальноукраїнської економіки.

Однією із особливостей економічного освоєння південноукраїнських земель можна вважати політику уряду щодо залучення до цього процесу іноземних переселенців з різних європейських країн, що підтверджується низкою документів. В історіографії відомий указ Катерини II від 19 квітня 1795 р., згідно 3 яким дмя комоністів проголошувалась низка пільг: будівництво кам'яного житла дмя тимчасового проживання, кредити на потреби господарства у розмірі 100-150 крб., свободу віросповідання, будівництво церков, звіцьнення від податків на 10 років тощо [10].

Окремі пільги купцям і ремісникам, в тому числі й іноземним, надавалися указом від 2 жовтня 1795 р. Усім, хто будував у містах Катеринославської та Вознесенської губерній заводи, фабрики, будинки, магазини або записувався до гільдій з відповідним капіталом, гарантувалося звільнення від податків і постоїв та право користування обіцяними раніше привілеями [11]. Зазначені документи $\epsilon$ підтвердженням урядової помітики соціально-економічного розвитку Південної України, яка базувалася на залученні іноземних колоністів, яких зацікавили привабливі перспективи. Серед іноземних переселенців були представники різних станів, етносів і віросповідань.

Про активну колонізацію південного регіону свідчить заснування 6 квітня 1800 р. у Катеринославі “Контори опікунства Новоросійських іноземних поселенців", яка в подальшому зазнала реорганізації й проіснувала вже у вигляді Опікунського комітету до 1871 р. До їі обов'язків входимо: вибір і купівля земель для колоністів, проїзд до місця проживання, надімення землею, влаштування, вирішення спірних питань тощо.

Після маніфесту Олександра І від 20 мютого 1804 р. розпочалась нова хвиля іноземної колонізації Південної України. Цього разу уряд запрошував мише вправних землеробів і ремісників, які володіли майном на суму 300 гульденів та мали свідоцтво магістра, що підтверджувало їх "добре ім'я" [12]. Так намагалися уникнути проникнення до Росії непорядних та некорисних дия неї європейських громадян.

М. Слабченко зробив спробу проаналізувати переселенську політику царського уряду в Степовій Україні й розглянути участь у заселенні та економічному освоєнні краю вихідців з різних українських і російських губерній та із-за кордону. Він негативно оцінював урядову політику іноземної колонізації південноукраїнських земель, вважаючи їі невірною i економічно необгрунтованою. На думку автора колонії іноземних переселенців виступали своєрідними контрагентами щодо поміщицьких господарств на початку XIX ст. Дослідник відзначав значну громадську солідарність іноземних колоністів, їх передові господарські практики, тривалу урядову протекцію, що значною мірою 
сприяло розквіту їхніх общин. Він підкреслював, що "колонія була кріпким конкурентом, тим більш, що й явцялася вона зі своєю громадською й господарчою іншою культурою" [15, с. 24].

Розуміючи небезпеку такої конкуренції поміщики намагалися всіляко дискредитувати колоністів. М. Слабченко навів цитату із щоденника д-ра К. Андрієвського, яка сповнена ненависті до німецьких переселенців: "Немцы, проживающие в колониях Новороссийского края, за исключением некоторых миц из общества менонитов, пьянством и мошенничеством могут служить примером першостепенным негодяям, которые однако ж, превосходят грубостью и самохвальстввом". Разом із цим у "Записках" Одеського сільськогосподарського товариства господарство німецьких колоністів завжди характеризувалось з найкращої сторони. У першій половині XIX ст., в цілому, не зазначено скарг на іноземних колоністів. Траплялися мише поодинокі випадки виселення їх за межі країни, як покарання за неблагонадійну поведінку. Так, з Одеси у 1823 р. "внаслідок негідних вчинків" був висланий колоніст А. Єрк [15, с. 25].

Припинення іноземної колонізації, на думку М. Сцабченка, обгрунтовується причинами економічного характеру. У 1810 p. урядом підраховано, що одна родина колоністів коштувала державі 5 тис. крб. Але масове переселення емігрантів тривало аж до 1819 р., доки російський уряд не відмовився від практики широкого запрошення колоністів до Півдня [15, с. 22].

Характерною ознакою соціально-економічного піднесення південного регіону стало заснування та швидкий розвиток міст. Цю тезу підтверджують i опубліковані "Статистичні дані про становище Новоросійського краю", де зазначено, що на 1859 р. у Південній Україні налічувалося 52 міста, серед яких: 12 - приморських та портових [1, арк. 79-81]. Згідно з даними, наведеними М. Слабченком, процес урбанізації

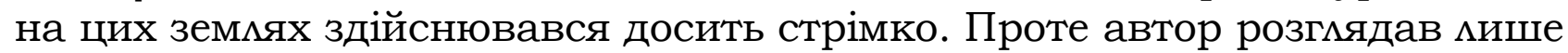
міста Херсонської та Кате-ринославської губерній в контексті інших міст Степової України (Волині, Київщини, Подімля, Чернігівщини, Харківщини, Полтавщини). Так на 1849 р. на Херсонщині налічувалось 18 міст і 64 містечка, а на Катеринославщині відповідно 11 і 14. Більше міст (19) бумо мише на Чернігівщині [15, с. 191].

У 1851 р. М. Мілютін опублікував статистичні дані стосовно кількості міст у Російській імперії в цілому і на Півдні зокрема. Наведені двома авторами кількісні показники практично не відрізняються, однак М. Мілютін вказав окремо кількість губернських, повітових і заштатних міст, до того ж не мише на землях вказаних М. Слабченком, але й в Таврійській губернії та Бессарабській області.

У Херсонській губернії за статистичними даними М. Мілютіна було засновано 6 губернських та повітових міст, 12 - заштатних і 64 містечка. У Катеринославській губернії, разом із Таганрозьким градоначальством, налічувалось 8 губернських та повітових міст, 3 заштатних та 14 посадів i містечок. Таврійська губернія мала 8 губернських і повітових, 8 заштатних міст і 6 посадів і містечок. 
Бессарабська область 3 Ізмаїльським градоначальством включала 8 повітових і губернських міст, 3 - заштатних та 28 посадів та містечок [4, с. 229-273].

У відповідності з наведеними даними найбільша кількість міських поселень виникла в Херсонській губернії (82), проте значну частину серед них становили містечка.

Міська колонізація знаходилась у тісній залежності від адміністративних потреб, стратегічних та економічних інтересів Росії в південному регіоні. Це спонукало до заснування адміністративних міст (Катеринослав, Вознесенськ), промислово-торгових міст (Херсон, Миколаїв) та причорно-морських портів (Одеса, Таганрог, Феодосія).

У планах уряду важлива роль спочатку відводимось Херсону, який мав стати центром суднобудування. Згідно з Указом Катерини II від 18 червня 1778 р. у місті передбачалась суднобудівна верф, торгова пристань та фортеця [8]. На будівництво Херсону виділялися значні кошти в розмірі 1825125 крб. 37 коп. А. Скальковский відзначав, що в 1784 р. у Херсоні буми завершені роботи по створенню Чорноморського фмоту, який скмадався із 12 мінійних суден та 17 фрегатів. Протягом 1779-1826 рр. у місті побудовано 152 судна, що вказує на поступове формування міста як центру суднобудування [13, с. 17, 31]. М. Слабченко навів деякі відомості про розгортання суднобудування в Херсоні та утворення перших акціонерних транспортних товариств.

Розглядаючи формування міського населення в контексті розвитку міст, М. Слабченко відзначив зростання чисельності купецтва за рахунок зменшення міщанства. Він висунув тезу про роль євреїв у цьому процесі, які займаючись здебільшого роздрібною торгівлею сприяли посиленню позицій купецтва. Дослідник підкреслював, що українське купецтво мише з 1824 р. "прибралося в загальноросійські форми", отримавши можливість записатися до відповідних гільдій. Дійсно, певна частина українців займалися торгів-лею і належала до стану купецтва. Серед них зустрічаємо прізвища одеських купців 1-ї гільдії І. Ващенка, М. Крамарева, Т. Яхненко, які відігравали важливу роль у зовнішній торгівмі. Зокрема, Т. Яхненко у 40-ві рр. був одним із найкрупніших купців Одеси. Його небіж і повірений С. Яхненко вів торгові справи в Англії, Нідерландах і Німеччині [3, с. 102].

М. Слабченко звертав увагу на появу так званих торгуючих міщан, які не маючи достатнього капіталу (5 тис. крб.) не могли записатися до жодної з гільдій. Дослідник дійшов висновку, що на зміну міщанського обліку міст приходив новий буржуазний. Наведені ним дані свідчать про те, що впродовж 1794-1851 рр. чисельність купців в Херсонській губернії зросла майже вдвічі, а міщан - більше, ніж у двічі. У Катеринославській губернії - відповідно у чотири і менш, ніж у три рази.

Проте, у відповідності з документальними матеріалами і статистичними даними найбільш чисельним станом в усіх містах Південної України було міщанство. Його правове становище зафіксоване у "Грамоті на права і вигоди містам Російської імперії" від 21 квітня 1875 р. [9]. Поряд із обов'язками, які помягали у сплаті податку та 
виконанні міщанських повинностей, цей стан мав свої права та привілеї, які передавались у спадщину. У південноукраїнських містах міщани могли вільно займатися ремеслами і торгівлею. Дия швидкого розвитку промисловості і торгівлі, уряд надавав їм низку пільг, які знайшли відображення у відповідних законодавчих актах, що й сприяло зростанню кількості міщан.

Так у містах Херсонської губернії впродовж 1824-1861 pp. чисельність міщанства виросла майже в чотири рази (в Одесі - майже в п’ять разів).

У містах Катеринославської губернії протягом 1833-1858 рр. кількість міщан теж збільшилась у чотири рази (у Катеринославі - в три). Проте його питома вага значно поступалась аналогічним показникам Херсонської губернії, що вказує на певне відставання промислово-торгового комплексу [2, с. 96-97].

у своїх дослідженнях М. Слабченко дотримувався концепції про вирішальну роль торгового капіталу в розвитку суспільства, що зумовимо підвищену увагу історика до розгортання зовнішньої торгівлі через причорноморські порти. На його думку, 3 одного боку, чорноморські порти стимулювали зростання іноземних капіталів, а 3 іншого - спонукали російських підприємців "пересуватися до північної частини України й спускатися на південь, де вступити в конкуруючу боротьбу з західно-європейськими заходьками" [15, с. 10].

Про активний розвиток торгівлі свідчить зростання купецтва в містах Південної України. Найбільш яскраво цей процес відбувався в Херсонській губернії, де впродовж 1833 -1861 рр. цей показник зріс у 6,5 разів. У 1833 р. тут проживав 241 купець 1-ї гільдії (з яких 220 осіб - в Одесі), а на кінець дореформеного періоду - 309 купців 1-ї гільдії (з них 284 - в Одесі).

У Катеринославській губернії купці 1-ї гільдії з'явимись мише на середину XIX ст. у кількості 16 осіб (13 - у Катеринославі, три - у Павлограді). Тут переважали купці 3-ї гільдії, які займалися внутрішньою торгівцею [2, с. 106-109, 112-114].

Варто вказати, що М. Слабченко досить однобічно підходив до причини коливань у хлібному експорті, вважаючи, що вона зумовлена консерватизмом поміщиків у веденні господарства. Успіхи Одеського порту в конкуренції з балтійськими портами історик пов'язував із наростанням ворожого ставлення російського купецтва до чорноморського міста. Дійсно, російські купці не відігравали провідної ролі у зовнішній торгівлі й пальма першості в ній належала грекам, яких з середини XIX ст. почали витісняти єврейські купці. Зростання їхньої чисельності відбувалось за рахунок певної кількості іноземців, що прийняли російське громадянство, отримавши при цьому ряд пільг i можливість вести морську торгівлю під російським прапором. У 1841 р. нею займались 113 купців 1-ї та 2-ї гільдій, серед яких 94 особи мали російське підданство. Однак корінним росіянином був мише один - Імля Новіков. Протягом 1842-1844 рр. кількість росіян серед купців залишилася незмінною, мише місце Іммі Новікова в міжнародній торгів і 
зайняв його син Яків. Іноземні купці, які прийняли російське підданство, розбагатівши часто поверталися на свою батьківщину [7]. Аналогічної думки дотримувався й К. Скальковський, який вважав, що в цілому чисельність російських купців 1-ї гільдії була незначною, до того ж вони не відзначалися особливою освіченістю та культурою. На їх фоні вигідно відрізнялися батько і син Новікови, які упродовж значного періоду часу були єдиними російськими купцями, що займались активною зовнішньою торгівлею, в тому числі й хлібною [14, с. 19].

Проте дехто з російських купців досягнув неабияких успіхів. Зокрема, одеський купець 1-ї гільдії А. Крамаров в кінці 20-х - на початку 30-х рр. XIX ст. здійснював значну оптову торгівцю через Одесу, Москву, Константинополь, Мессіну, Ціворно, Геную, Марсемь і Аондон. У 1830 р. у Міністерстві фінансів розглядалося питання про надання йому звання радника комерції [3, с. 102].

Російські купці більш плідно займалися проблемами внутрішньої торгівлі й організували низку ярмарків, які двома мініями охопили весь Південь. Перша 3 них простяглася вздовж Дніпра в напрямі чорноморських портів, а друга - пролягла між Дніпром і Донцом 3 виходом до азовських портів. Великі ярмарки відбувалися у Катеринославі, Єлисаветграді, Новомосковську, Одесі, Каховці та багатьох інших містах [5, с. 226]. Тож завдяки купецтву буми налагоджені тісні торгові зв'язки з різними регіонами України та Росії.

У своїх дослідженнях М. Слабченко розглянув й інші питання соціально-економічного розвитку Південної України в дореформений період. Ним вперше введено до наукового обігу значну кількість статистичних відомостей, які автор зібрав у фондах архівів, рукописних фондах бібліотек тощо. До того ж він широко використав дані, які приводились у дослідженнях істориків та економістів, критично проаналізувавши деякі положення цих робіт. Безумовно, його дослідження, гіпотези і висновки є хорошим підгрунтям дмя вивчення соціально-економічної історії XIX ст.

\section{Джерема та мітература:}

1. Держархів Одеської області. - Ф. 3. - Оп. 1. - Спр. 50.

2. Діанова Н. М. Формування населення міст Південної України у дореформений період (кінець XVIII ст. - 1861 р.): дис... к. і. н. : 07.00 .01 / Н. М. Діанова: ОНУ імені I. І. Мечникова. - Одеса, 2003. - 208 с.

3. Історія Одеси / Кол. авторів. Головн. ред. В. Н. Станко. - Одеса: Друк, 2002. $560 \mathrm{c}$.

4. Мимютин Н. А. Число городских и земледельческих поселений в России / Н. А. Мимютин // Сборник статистических сведений о России, издаваемых статистическим отделением Императорского РГО. - СПб., 1851. - С. 229-273.

5. Миронов Б. Н. Внутренний рынок России во второй половине XVIII первой половине XIX векав / Б. Н. Миронов. - ^.: Наука, 1981. - 259 с.

6. Оглоблин А. П. Очерки истории украинской фабрики. Предкапитамистическая фабрика / А. П. Оглоблин. - К.: Государственное издательство Украины, 1925. - 234 с.; Оглоблін О. Нариси з історії капіталізму на Україні / О. Оглоблін. - Харків-Київ, 1931. - 174 с. 
7. О торговом сословии Одессы, особенно русском // Одесский вестник. 1845. - 25 апреля, 28 апреля.

8. Полное собрание законов Российской империи. Собрание I. (далі - ПСЗРИI). - Т. XX. - СПб., 1830. - № 14764.

9. ПСЗРИ-І. - Т. ХХІІ. - СПб., 1830. - № 16188.

10. ПСЗРИ-І. - Т. ХХІІІ. - СПб., 1830. - № 17320.

11. ПСЗРИ-І . - Т. ХХІІІ. - СПб., 1830. - № 17392.

12. ПСЗРИ-І. - Т. ХХVIII. - СПб., 1830. - № 21163.

13. Скальковский А. Херсон с 1774 до 1794 г. / А. Скальковский. - СПб., 1836. - 32 c.

14. Скальковский К. Воспоминания молодости: По морю житейському, 18431869 / К. Скальковский. - СПб.: тип. А. Суворина, 1906. - 410 с.

15. Слабченко М. Матеріали до економічно-соціальної історії України XIX ст. / М. Слабченко. - Одеса: ДВУ, 1925. - Т. 1. - 318 с.

\section{References:}

1. Derzharkhiv Odes'koyi oblasti. - F. 3. - Op. 1. - Spr. 50.

2. Dianova N. M. Formuvannya naselennya mist Pivdennoyi Ukrayiny $u$ doreformenyy period (kinets' XVIII st. - 1861 r.): dys....k. i. n. : 07.00 .01 / N. M. Dianova: ONU imeni I. I. Mechnykova. - Odesa, 2003. - 208 s. [In Ukrainian].

3. Istoriya Odesy / Kol. avtoriv. Holovn. red.r. V. N. Stanko. - Odesa: Druk, 2002. - 560 s. [In Ukrainian].

4. Milyutin N. A. Chislo gorodskikh i zemledel'cheskikh poseleniy v Rossii / N. A. Milyutin // Sbornik statisticheskikh svedeniy o Rossii, izdavaemykh statisticheskim otdeleniem Imperatorskogo RGO. - SPb., 1851. - S. 229-273.

5. Mironov B. N. Vnutrenniy rynok Rossii vo vtoroy polovine XVIII - pervoy polovine XIX vekav / B. N. Mironov. - L.: Nauka, 1981. - 259 s. [in Russian].

6. Ogloblin A. P. Ocherki istorii ukrainskoy fabriki. Predkapitalisticheskaya fabrika / A. P. Ogloblin. - K.: Gosudarstvennoe izdatel'stvo Ukrainy, 1925. - 234 s.; Ohloblin O. Narysy $z$ istoriyi kapitalizmu na Ukrayini / O. Ohloblin. - KharkivKyyiv, 1931. -174 s. [In Ukrainian].

7. O torgovom soslovii Odessy, osobenno russkom // Odesskiy vestnik. - 1845. 25 aprelya, 28 aprelya.

8. Polnoe sobranye zakonov Rossyyskoy ymperyy. Sobranye I. (dali - PSZRY-I). -

T. XX. - SPb., 1830. - № 14 764. [in Russian].

9. PSZRI-I. - T. XXII. - SPb., 1830. - № 16188.

10. PSZRI-I. - T. XXIII. - SPb., 1830. - № 17320.

11. PSZRI-I. - T. XXIII. - SPb., 1830. - № 17392.

12. PSZRI-I. - T. XXVIII. - SPb., 1830. - № 21163.

13. Skal'kovskiy A. Kherson s 1774 do 1794 g./A. Skal'kovskiy. - SPb., 1836. $32 \mathrm{~s}$.

14. Skal'kovskiy K. Vospominaniya molodosti: Po moryu zhiteys'komu, 18431869 / K. Skal'kovskiy . - SPb.: tip. A. Suvorina, 1906. - 410 s. [in Russian].

15. Slabchenko M. Materialy do ekonomichno-sotsial'noyi istoriyi Ukrayiny XIX st. / M. Slabchenko. - Odesa: DVU, 1925. - T. 1. - 318 s. [In Ukrainian]. 
наталия дианова

Особенности социацьно-экономического развития Южной Украины в первой помовине XIX в. в контексте исследований М. Е. Сцабченко

В представленной научной статье сделана попьтка исследования особенностей соииально-экономического развития Южной Украины в дорефрорменный период в контексте исследований $M$. Слабченко. Рассмотрены истоки иностранной колонизаиии на Юге и оиенка этого проиесса в работах М. Слабченко. Исследователь сиитал политику правительства по привлечению иностранных переселениев неправильной и экономически необоснованной.

Показано, что характерной особенностью соииально-экономического развития Южной Украины бъло основание и быстрое развития городов. На основании обработанных источников М. Слабченко утверждал, что проиесс урбанизаиии на землях Юга осуиествлялся достаточно быстро. Это подтверждается статистическими данньми 1851 г.

Рассматривая формирование городского населения М. Слабченко приоритетную роль отводил купечеству, которое изменило мешанский облик городов на буржуазный. В контексте исследуемой темы научный интерес представляют опубликованные и архивные документы, которые дают возможность рас-смотреть некоторые аспекты представленной темы.

Проанализирована кониепиия Михаила Елисеевича о решаюшей роли торгового капитала в развитии общества и причерноморских портов в экономической истории Украины.

ключевые слова: сочиально-экономическое развитие, М. Слабченко, Южная Украина, города, торговля, купечество.

Отримано: 09.09.2018 р. 